\title{
EXPERIMENTAL STUDIES ON THE HOMOGENEITY AND COMPRESSIVE STRENGTH PREDICTION OF RECYCLED AGGREGATE CONCRETE (RAC) USING ULTRASONIC PULSE VELOCITY (UPV)
}

\author{
Nuraziz Handika ${ }^{*}$, Balqis Fara Norita ${ }^{1}$, Elly Tjahjono ${ }^{1}$, Essy Arijoeni $^{1}$ \\ ${ }^{1}$ Department of Civil Engineering, Faculty of Engineering, Universitas Indonesia, Depok 16424 \\ Indonesia
}

(Received: May 2020 / Revised: July 2020 / Accepted: September 2020)

\begin{abstract}
The reuse of material from collapsed building debris as a natural aggregate substituent has been an alternative to solve concrete waste in Indonesia. However, its use in larger structures needs further research. The objectives of this research are to study the concrete homogeneity at a certain sample height and to find the strength prediction of Recycled Aggregate Concrete (RAC). In the previous laboratory study, the obtained concrete compressive strength with $20 \%$ RAC substitution (from the concrete ruins with $\mathrm{fc}^{\prime}=30 \mathrm{MPa}$ ) was 27-30 $\mathrm{MPa}$. Since, RAC contains natural aggregates and mixed cement paste, it is important to research the distribution, homogeneity and strength prediction of the concrete. The measurement was done using a nondestructive instrument called Ultrasonic Pulse Velocity (UPV). This paper presents a series of experiments investigating homogeneity and predicting compressive strength using both Destructive and Non-Destructive Tests (NDT). To do so, three steps in the experimental works were done. Firstly, UPV propagation measurements at four different levels through vertical prismatic beam specimens was performed. Two transducers were used in the direct mode of transmission with a $15 \mathrm{~cm}$ distance of measurement. Secondly, identical concrete samples cast in cubic form were measured using UPV and tested under compression. Thirdly, the coredrilled samples were taken from the vertical prismatic beam specimens for further investigation. The wave propagation velocity through RAC and the concrete compressive strength relationship demonstrate similar pattern as concrete with GFC (Gypsum-free-cement) performed by Brozovsky. This pulse velocity-concrete strength relationship can be used to predict the strength of RAC. Both the prediction curve and the homogeneity properties can be useful when casting a larger element of structures using RAC.
\end{abstract}

Keywords: Concrete Compressive Strength; Homogeneity; Non-Destructive Test; Recycled Aggregate Concrete; Ultrasonic Pulse Velocity

\section{INTRODUCTION}

As one of the most commonly used building materials, most of the concrete waste is largerly produced in Indonesia. Some activities have been conducted to reuse collapsed building debris such as recycled aggregates as an alternative material to overcome concrete waste in Indonesia.

\footnotetext{
*Corresponding author's email: n.handika@ui.ac.id, Tel. +62 81381473262

DOI: https://doi.org/10.32783/csid-jid.v3i2.111
} 
Studies on the use of recycled aggregates have been performed extensively, including studies on the effective percentage of recycled aggregate, the effect of demolished aggregate used in concrete, and, the use of RAC for high strength concrete (Adnan et al., 2007; American Concrete Institite, 2001; Qasrawi et al., 2013; Vyas \& Bhatt, 2013; Wulandari, 2008).

The compressive strength of the recycled aggregate concrete depends on the quality of the used aggregate (Malešev et al., 2010). It has the possibility of higher, equivalent or lower compressive strength compared to the concrete that uses natural aggregates. As a result, the concrete with recycled aggregate tend to have higher compressive strength than the normal one. In this case, recycled aggregate from crushing concrete that has the same compressive strength as the targeted value, the compressive strength showed 5\% to 10\% lower than the comparable normal concrete.

In the case of normal concrete with natural aggregates, the increase in compressive strength is typically higher than the recycled concrete when reaching 28 days. On the contrary, the increase in the compressive strength is higher for recycled concrete compared to concrete with natural aggregates when over 28 days. This condition can occur due to the hydration process of the cement paste attached to the recycled aggregate (Malešev et al., 2010).

In terms of concrete homogeneity, it is important to study the use of special aggregates on the segregation. Due to the condition of the recycled aggregate, (it may contain paste or only natural aggregate, and/ or a combination of both), the uniformity of the RAC may vary throughout a certain volume. The non-homogenous strength of a concrete volume is an example of a serious problem related to the drawbacks of material segregation (Benaicha et al., 2015). This condition must be avoided if the RAC is applied to larger structures. It is also obvious that the RAC's homogeneity needs to be further examined.

In the modern construction world, non-destructive test (NDT) has become an important part of the process of monitoring the quality of concrete structures (Gupta, 2018; Lorenzi et al., 2007). NDT can measure durability issue and predict compressive strength of concrete structures. The main purpose of NDT is to test concrete properties in-situ without damaging the concrete structure. The NDT method has been widely applied in concrete studies such as in the use of Ultrasonic Pulse Velocity (UPV) or ultrasonic wave velocity which is then used to determine the quality of the concrete structures (Gehlot et al., 2016; Güneyli et al., 2017; Karaiskos et al., 2015; Majeed \& Khalaf, 2018; Rao et al., 2016; Yap et al., 2013). Nevertheless, the wave propagation measurements are affected by the characteristics of the concrete mixtures which can lead to difficult interpretations (Benaicha et al., 2015; Karaiskos et al., 2015; Saint-Pierre et al., 2016). UPV has the capacity to propagate through a mass of concrete. Testing the wave propagation in a specimen from different positions can be used to interpret the condition within the concrete. In this research, propagation through RAC can be used to see the homogeneity of a concrete mass. Furthermore, the propagation describes density of concrete. UPV measurement on destructive test specimen can be used to predict concrete strength.

The objectives of this research are twofold, to verify the homogeneity of RAC along with the height of the specimen, and to obtain the compressive strength and ultrasonic wave velocity relationship. This relationship can be used to estimate the RAC compressive strength. It can help in the application of RAC when producing larger element of structures. For example, predicting strength of the beam using RAC materials so that the demoulding and transportation processes can be done safely. To do so, the ultrasonic pulse velocity (UPV) measurements through a concrete sample were performed to interpret the homogeneity of RAC, and to predict the RAC compressive strength. The selected concrete waste (concrete ruins of $30 \leq \mathrm{fc}$ ' $^{2} \leq 35$ $\mathrm{MPa}$ ) was used as natural aggregate substitution material for the new concrete. The same mix 
proportion of concrete from the previous studies that resulted RAC with $28-30 \mathrm{MPa}$ of compressive strength was used (Duma, 2008; Marastuti, 2014; Wulandari, 2008).

There were three main experimental sets in this research. The first experiment monitored the local changes in the ultrasonic velocity propagation of the concrete vertical beam using the proposed method by Benaicha et.al (2015) since the earlier ages of the concrete. The sample size was adjusted on the basis of the application of concrete using an alternative aggregate applied to the larger structural element (Dini Sofyani et al., 2019; Handika et al., 2019). The second experimental campaign consisted of the measurement of wave propagation velocity and destructive tests according to the set standards for the identical concrete samples cast in cubic shape at $15 \times 15 \times 15 \mathrm{~cm}^{3}$. The last experiment consisted of a study of the core-drilled samples taken from the vertical prismatic beam specimens. These core-drilled samples were also measured by UPV.

\section{MATERIAL CHARACTERISATION: RECYCLED AGGREGATE CONCRETE (RAC)}

There were two mixed proportions used in this study. The first proportion used $100 \%$ Natural Coarse Aggregate for Normal Concrete (NC), and the second proportion used 20\% RAC substitution of coarse aggregate with Superplasticizer (SP). The $20 \%$ of RAC was found to be the most effective proportion to achieve the target strength of recycled aggregate concrete (Marastuti, 2014). The complete mix proportion of concrete in this paper is shown in Table 1 . The first proportion was used only as a control for the cubic specimen. The recycled aggregate was obtained from the crushing of a cylindrical sample with a compressive strength between 27 and $30 \mathrm{MPa}$. The condition of the aggregate can be seen in Figure 1. The preparation of the recycled aggregate was carried out based on the previous research (Duma, 2008; Marastuti, 2014; Wulandari, 2008). This experimental campaign used local sand from Parung, West Java with a maximum size of $4 \mathrm{~mm}$ and a fine modulus of 2.81 . For the two mixed proportions, Portland Composite Cement (PPC) that comply with national and international standards were utilized. Superplasticizer (SP) MasterGlenium SKY 8851 BASF was also used. Different ratios of $\mathrm{W} / \mathrm{C}$ were used as the recycled one needs more water than the normal one.

Table 1 Mixed design of Recycled Aggregate Concrete (RAC)

\begin{tabular}{lcc}
\hline \multicolumn{1}{c}{ Items } & RAC & NC \\
\hline W/C & 0.425 & 0.40 \\
Water $\left(\mathrm{kg} / \mathrm{m}^{3}\right)$ & 195 & 195 \\
Sand $\left(\mathrm{kg} / \mathrm{m}^{3}\right)$ - Parung sand size $0-4.0 \mathrm{~mm}$ & 760 & 760 \\
Natural Aggregates (coarse aggregates) $\left(\mathrm{kg} / \mathrm{m}^{3}\right) 4.75-12.5 \mathrm{~mm}$ & 778 & 945 \\
Recycled Aggregates (coarse aggregates) $\left(\mathrm{kg} / \mathrm{m}^{3}\right)$ & 167 & - \\
Superplasticizer (SP) MasterGlenium SKY 8851 BASF $\left(\mathrm{kg} / \mathrm{m}^{3}\right)$ & 2.20 & - \\
\hline
\end{tabular}

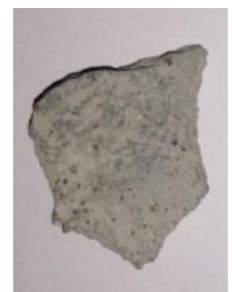

(a)

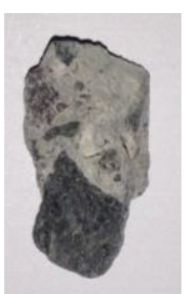

(b)

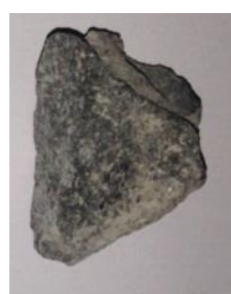

(c)

Figure 1 Three conditions of recycled aggregate from the crushing of the cylindrical specimen

(a) Aggregate is entirely covered by cement paste. (b) Aggregate is partially covered by cement paste.

(c) Aggregate is not covered by cement paste. 


\section{EXPERIMENTAL WORKS}

There were three main experimental works performed in this research. The first experiment was carried out to measure wave propagation through RAC from the earliest age of the concrete. This measurement expected to study the homogeneity of concrete. The sample was in the form of vertical beams ( 5 samples) presented in Figure 2 (a). The second experiment is to determine the relationship between wave propagation through RAC and the compressive strength of the cubic sample. The measurement was performed at the age of 3, 7, 14, 28 and 56 days (3 samples each). The third experiment is to study the core-drilled sample taken from the vertical prismatic beam specimens.

\subsection{Ultrasonic Pulse Velocity (UPV)}

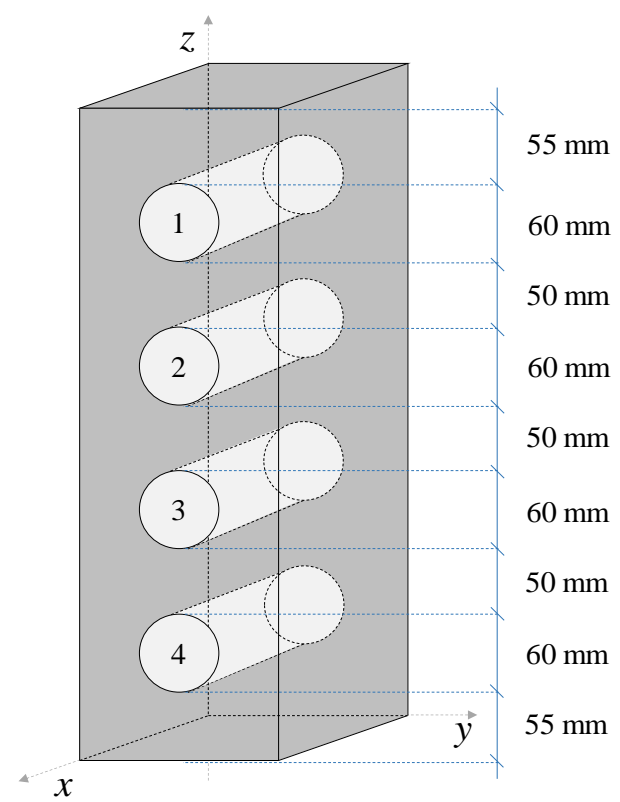

(a)

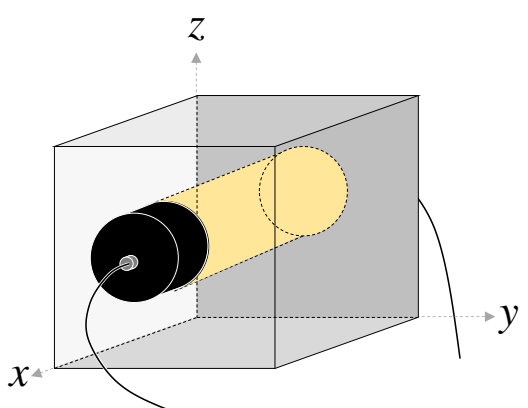

(b)

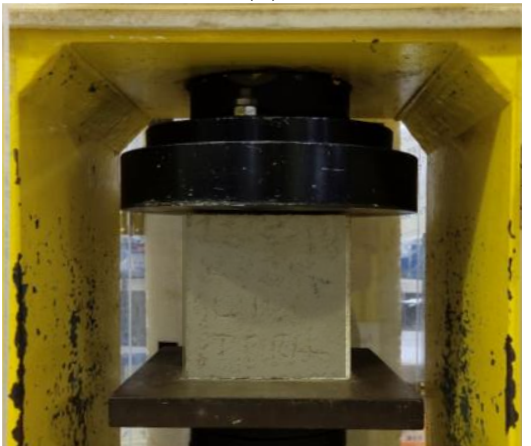

(c)

Figure 2 Experimental works

(a) Plexiglas vertical beam used to measure ultrasonic velocity from the earliest age stages. (b) Measurement using the UPV equipment. (c) Concrete compressive test using a compression machine.

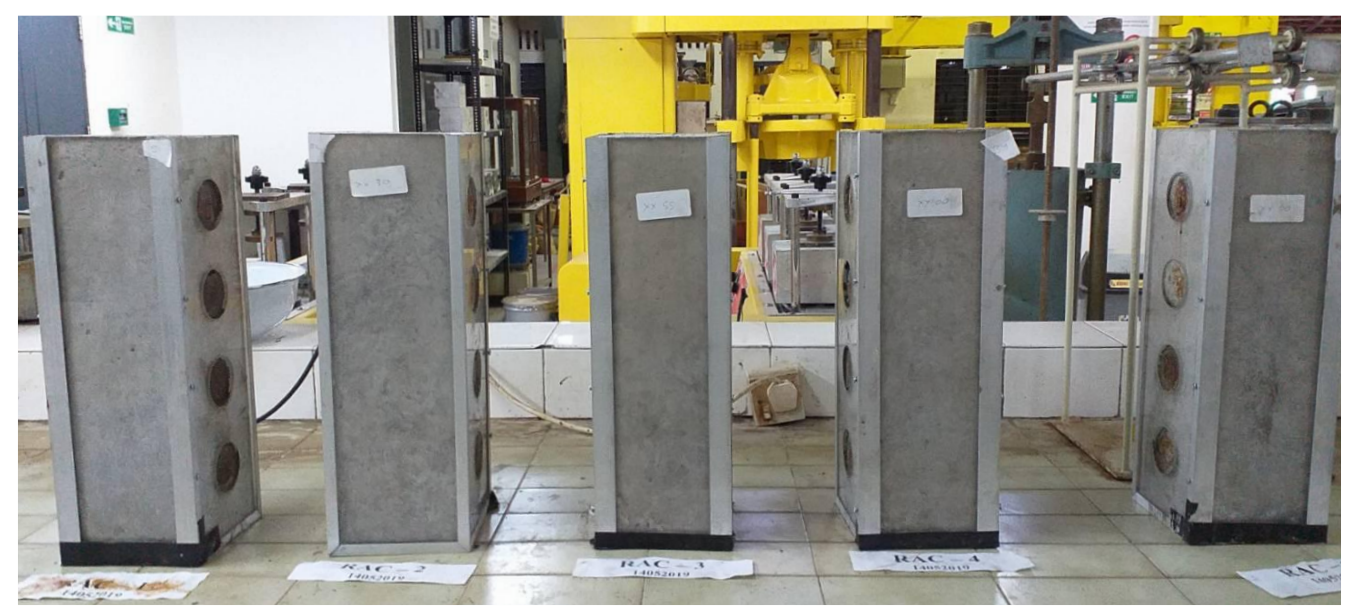

Figure 3 Five samples from the vertical beam of RAC 
Details of the vertical beam specimen are shown in Figure 2 (a). The dimension proposed by Benaicha et al (2015) was adjusted accordingly. Hole number 4 and number 1 is separated by $280 \mathrm{~mm}$ in height at the mid-point of the measurement. This condition was chosen because of the dimensions of the beam in the previous studies (Dini Sofyani et al., 2019; Handika et al., 2019). For the NDT measurements, five Plexiglas moulds with a height of $500 \mathrm{~mm}$ and $150 \mathrm{~mm}$ $\times 150 \mathrm{~mm}$ were used placed in cross-section (see Figure 3).

The ultrasonic pulse velocity (UPV) unit consists of two transducers. One transducer works as an emitter and the other one as a receiver. Dimension of the transducer rod is $50 \mathrm{~mm}$ of diameter with an amplifier, and a main control unit. The two transducers were positioned in the $x$-direction as shown in Figure 2 (a). For this study, a direct measurement was performed for all samples. During the measurements, the two transducers were positioned aligned at the same level opposite each other (American Society for Testing and Materials, 2002).

The wave propagation measurement through the RAC was conducted from 4 hours until the sample was 56 days old. During the measurement, the concrete must be properly hardened. One measurement was taken at the age of 122 days after the demoulding. The measurement of time for wave propagation was conducted 3 times for each level. The tabulated transit time $(\mathrm{T})$ was then converted to velocity.

\subsection{Cubical Specimen}

Specimens in cubic form with a scale of $150 \times 150 \times 150 \mathrm{~mm}^{3}$ were tested destructively and non-destructively. In order to find the compression strength (fc'), the cubic samples were tested using international standard (British Standard Institute, 2009). The conversion of experimental results on cubic specimen to fc' was performed (Arijoeni and Setiadi, 1998). The relationship between concrete compressive strength $(\mathrm{MPa})$ and wave propagation velocity $(\mathrm{km} / \mathrm{s})$ could thus be examined. Figure 2 (b) describes the NDT (Non-Destructive Test) using UPV by means of a cubic specimen test. The measurement of the wave propagation was performed 3 times for each sample.

\subsection{Drilled Concrete Core Samples from the Vertical Beam}

Five vertical beam samples as described in section 3.1 were non-destructively tested and then drilled in three different ways. Samples were picked at random. Three of the five samples were drilled vertically (z-direction) as presented in Figure 2 (a). One sample was drilled in the xdirection (horizontal) and the other was drilled in the y-direction (horizontal). Coring was performed when the concrete hit 122 days (American Concrete Institite, 2010; American Society for Testing and Materials, 2018). The vertical core-drilled sample in the vertical direction was then cut into 3 samples; upper, middle and lower parts. All core drill samples compressed by following international standard (American Society for Testing and Materials, 2018). The correction of compression test on core-drilled specimen was performed (Badan Standarisasi Nasional, 2002).

\section{RESULTS AND DISCUSSION}

\subsection{Wave Propagation in Vertical Beams RAC for Homogeneity Investigation}

The measurement technique for the wave propagation through RAC in the 5 vertical beam (VB) samples was shown in Figure 2a. The measurement of the fresh concrete using UPV was able to be started after 4 hours of casting. The measurement of wave propagation at each level (level 1 until 4) is recorded during the experiment. In order to investigate the homogeneity, the Homogeneity Coefficient (HC) formulation is used (Benaicha et al., 2015). The formulation aims to measure the stability of self-compacting concrete. The HC value is obtained from the derivation of the measured velocity of point 4 and point 1 respectively. This means that the HC 
scale is used to calculate the homogeneity of the upper and the lower part of the VB specimen. Benaicha (2015) claimed that material has high stability when HC value between 0.98 and 1.02.

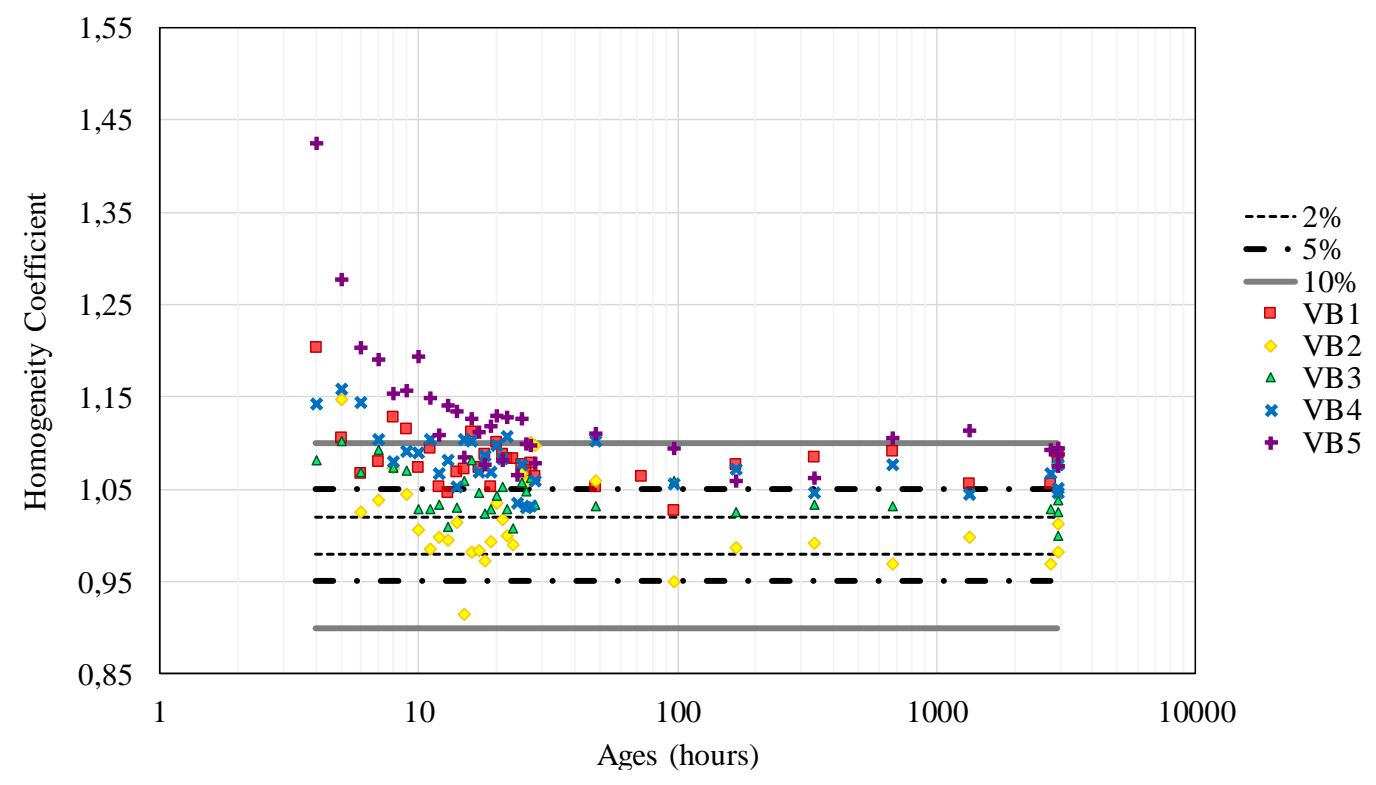

Figure 4 The evolution of the homogeneity coefficient using the proposed formulation by Benaicha

(Benaicha et al., 2015)

The HC of the 5 vertical beams (VB) is shown in Figure 4. According to Benaicha et al (2015), all samples do not follow the $2 \%$ of $\mathrm{HC}$ requirement, in other words, the material has low stability. As the proposed formulation was intended for self-compacting concrete, therefore, this formulation may not be suitable for other types of concrete, in this case concrete with recycled aggregate.

As standard ACI 214 (American Concrete Institute, 2010) does not regulate the acceptance criteria for normal concrete homogeneity using UPV, this research adopts the tolerance variation of the acceptable concrete compressive based on ACI 318 (American Concrete Institite, 2019) and Indonesian Standard SNI 2847 in 2013 (Badan Standarisasi Nasional, 2013). The tolerance is $10 \%$ which therefore all of the specimens can be accepted (see Figure 5). Previous section discussed the dimension of VB sample that was chosen based on the beam's height. The distance between hole 1 and 4 represents the height of the beam (Dini Sofyani et al., 2019; Handika et al., 2019). Therefore, the density variation of concrete in the upper part and the lower part since the beginning is less than $10 \%$. Moreover, the variation larger than 5\% occurred at the first 11 hours of concrete's age. When concrete was 28 days old (672 hours), the variation was below 4\%. This condition is verified in Section 4.3, which presents the core-drilled sample of VB3. The distribution of aggregates in the upper and the lower part can be visually distinguished. 


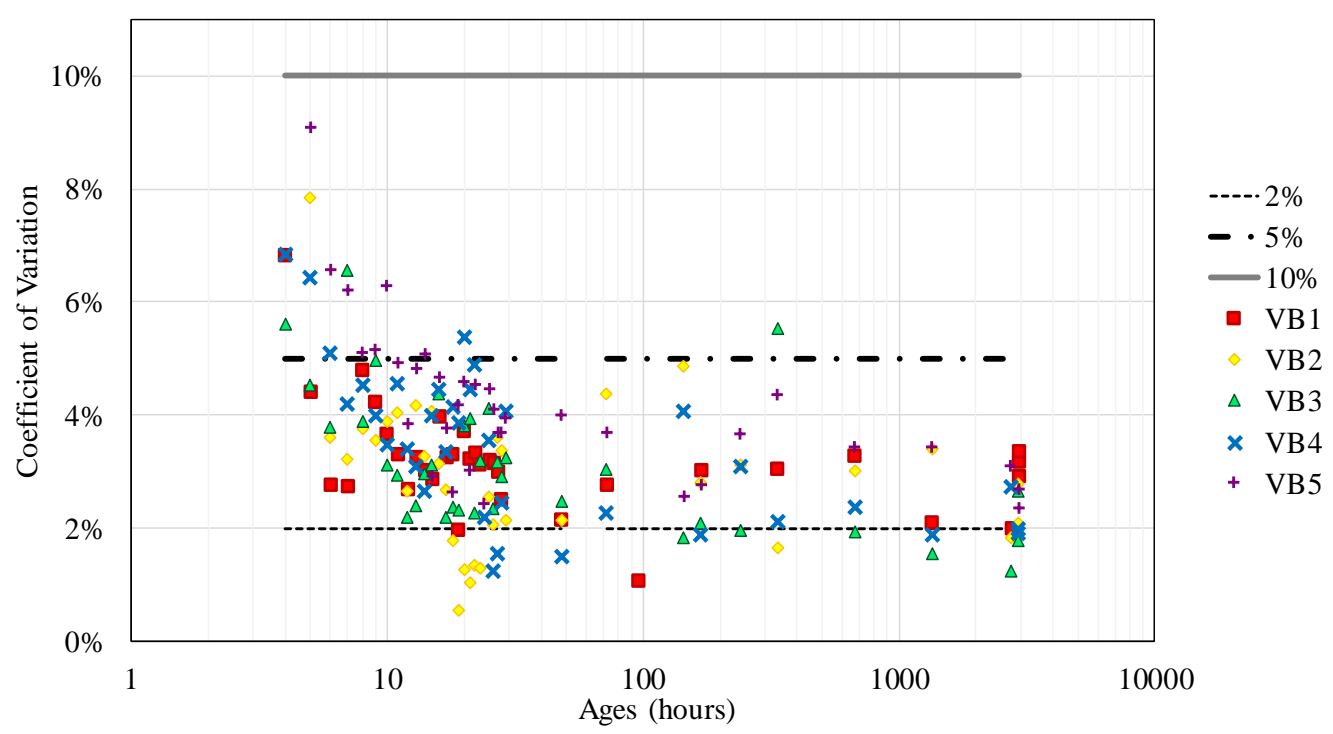

Figure 5 The evolution of the coefficient of variation based on SNI 2847:2013

\subsection{Evolution of UPV and the Age Relationship of RAC}

Figure 6 presents the experimental results of the UPV measurement againts the age evolution using a logarithmic scale in $x$-axis. The five curves are the average values (from the 4 points of measurement) of the wave propagation measurement of the five samples. The five samples experiencing similar trend. The velocity increases when the concrete is hardened (up to 28 days). This condition indicates the concrete is getting denser, and the UPV is getting faster. On the other hand, the velocity decreases after 28 days (672 hours). This condition should be investigated through a physical behaviour. The measurement at 122 days was performed after the samples were demoulded.

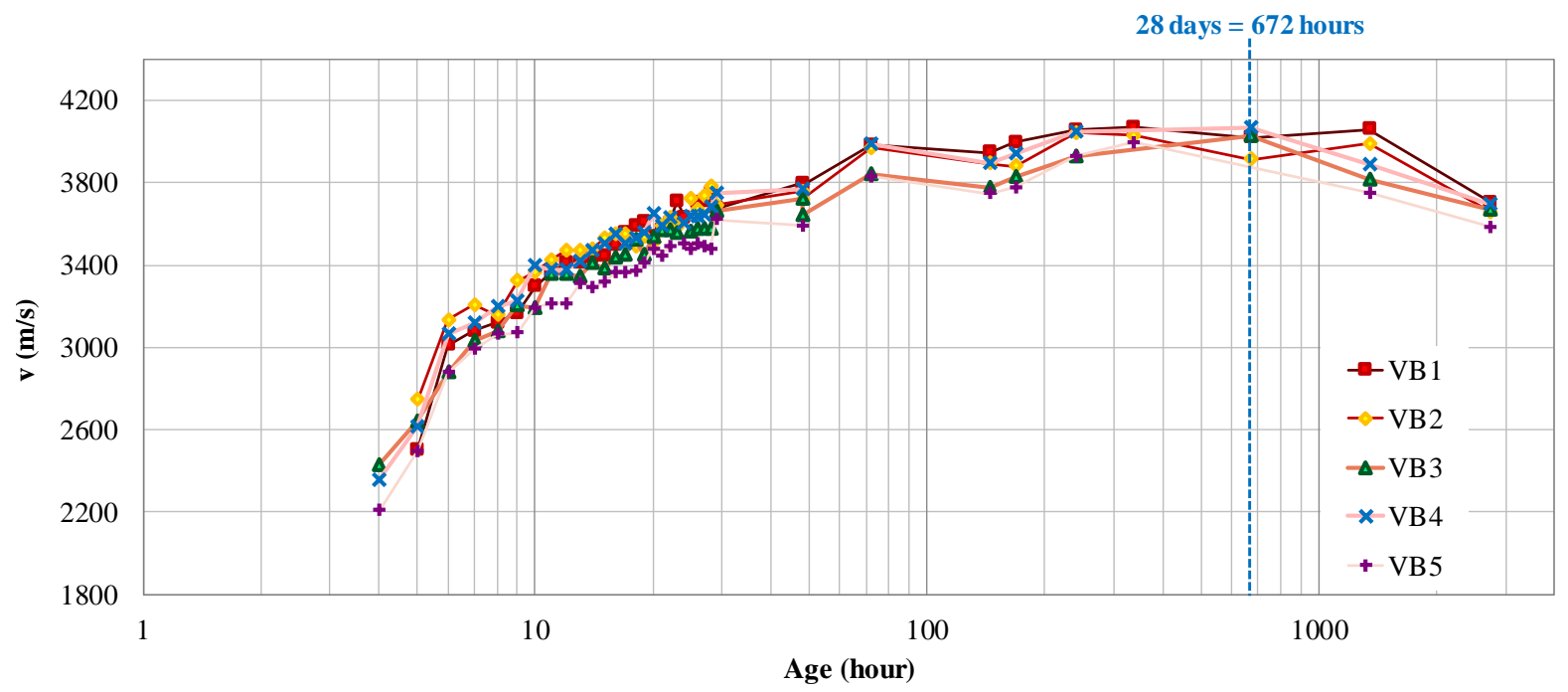

Figure 1 Evolution of UPV and the age relationship of RAC

\subsection{Core Drilling of the RAC Vertical Beam Specimens}

After the UPV measurement through the RAC vertical beam, the five samples were coredrilled. It was taken in $x-x, y-y$ and $z-z$ directions as shown in Figure 2 . The objective of the core-drilled sample investigations was to examine the distribution of aggregates along the sample and to examine UPV propagation, specifically in $z-z$ direction. A sample of the core drilling in the vertical direction is presented in figure 7 . Due to the length of the core barrel, the 
process of coring was divided into two parts. Figure 7 shows the uniform distribution of aggregate along the height of the vertical beam (VB). Nevertheless, coarse aggregate of the lower part found to be denser than the upper part. This condition affected the compressive test results and the UPV propagation at level 1 and 4.

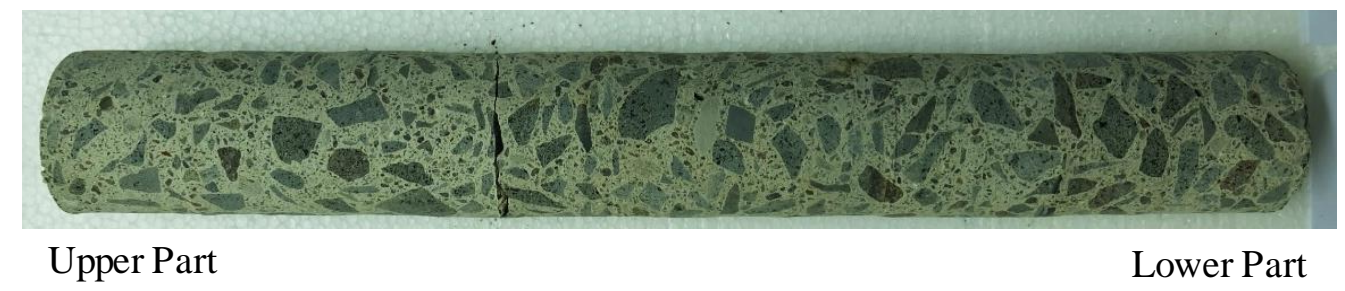

Figure 7 Long core-drilled samples from VB3 RAC

\subsection{The Relation Between UPV and RAC Strength}

The relationship between UPV and RAC strength is discussed in this section. There are three types of sample in this curve shown in Figure 8 consist of the cubic sample RAC, the control sample of normal concrete (NC-Control), and the core-drilled sample (RAC-Core). These samples were tested at the age of 3 to 56 days, while RAC-core samples were further tested at 122 days of age. In total there are 15 samples with 3 core-drilled sample from each VB. Figure 8 also showed characteristic of concrete strength from cubic type of samples and corrected compressive strength from core-drilled samples.

After being sawn, the RAC-Core samples were left to dry. They were then measured by UPV and tested for compressive strength in accordance with the ASTM C42 standard. Average strength, standard deviation and coefficient of variation of RAC, NC-Control, and RAC-Core sample types are shown in Table 2. The variation is high (larger than 10\%) according to (Badan Standarisasi Nasional, 2013) because the tests were not at the same concrete period, except for the RAC-Core sample tested at 122 days of age. While all the samples were tested at the same day, the RAC-Core showed high variation. Further investigation on RAC-Core samples reveals most of the upper part samples (4 out of 5 samples) had the lowest compressive stress between the middle and the lower part samples. On the other hand, 3 out of 5 lower part samples had the highest compressive strength. The distribution of aggregates along the core-drilled sample described in Figure 7. The coarse aggregate distribution proved to have an affect on the results of compressive strength test. The effect of aggregate distribution can also be seen on the UPV measurements. The lower samples have the highest velocity propagation across the concrete (the concrete is denser than the upper samples).

Table 2 Concrete strength: average, standard deviation and coefficient of variation

\begin{tabular}{lrrr}
\hline & \multicolumn{1}{c}{ RAC } & NC-Control & RAC-Core \\
\hline Average strength (MPa) & 27.07 & 25.74 & 29.33 \\
Standard deviation (MPa) & 6.80 & 4.92 & 6.22 \\
Coefficient of variation (\%) & 25.13 & 19.11 & 21.20 \\
\hline
\end{tabular}

The relationship between UPV and RAC strength is shown in Figure 8. RAC samples were taken using an exponential regression (following Equation 1) with the coefficient of determination $\mathrm{R}^{2}$ equal to 0.75 . Some of the existing relationship models were proposed by several codes and research such as from the local laboratory work (Laboratory of Structural and Material Universitas Indonesia, 2009), and international publication and standards (American 
Concrete Institite, 2003; British Standards Institution, 2007; Brožovský, 2009; Brozovsky et al., 2007; Brožovský et al., 2005). All of the equations are listed below where $f_{c}^{v}$ is the concrete compressive strength $(\mathrm{MPa})$ and $v$ is the wave propagation velocity through the concrete $(\mathrm{km} / \mathrm{s})$.

$$
f_{c}^{\prime}(v)=0.015^{1.728(v)} \text { with } v \text { in }[\mathrm{km} / \mathrm{s}] \text { and } f_{c}^{\prime} \text { in }[\mathrm{MPa}]
$$

Local laboratory work (Laboratory of Structural and Material Universitas Indonesia, 2009)

$$
f_{c}^{\prime}(v)=0.7045 v^{5}-10.37 v^{4}+61.266 v^{3}-175.83 v^{2}+247.19 v-123.47
$$

EN 13791 (British Standards Institution, 2007)

$$
f_{c}^{\prime}(v)=62.5 v^{2}-497.5 v+990 \text { with } 4 \leq v \leq 4.8[\mathrm{~km} / \mathrm{s}]
$$

CSN 731373 (Brožovský, 2009; Brozovsky et al., 2007; Brožovský et al., 2005)

$$
\begin{gathered}
f_{c}^{\prime}(v)=9.9 v^{2}-56 v+87.3 \\
f_{c}^{\prime}(v)=0.0133 v^{5.6344} \\
f_{c}^{\prime}(v)=0.0027 v^{6.2478}
\end{gathered}
$$

All of the normal concrete results are plotted (see Figure 8). The results of the RAC UPV-fc' relationship have similar pattern with Brozovsky - GFC Gypsum Free Cement. Moreover, the Brozovsky's formulation pattern yields similar results as ACI 228.1R-03. The RAC model formulation has also identical shape curve as both Brozovsky and ACI 228.1R. This means that concrete using recycled aggregates has similar fc'-UPV relationship as Brozovsky GFC. During this investigation, the effect of the chemical compound in the material was ignored as the type of cement meets the standard of SNI 7064 in 2014. Further investigations on the formulation for RAC and Brozovsky - GFC Gypsum Free Cement were also studied for the $1 \mathrm{~m} / \mathrm{s}$ interval of velocity. The rise in the delta compressive strength of the same velocity is $16.34 \%$ of the coefficient of variation.

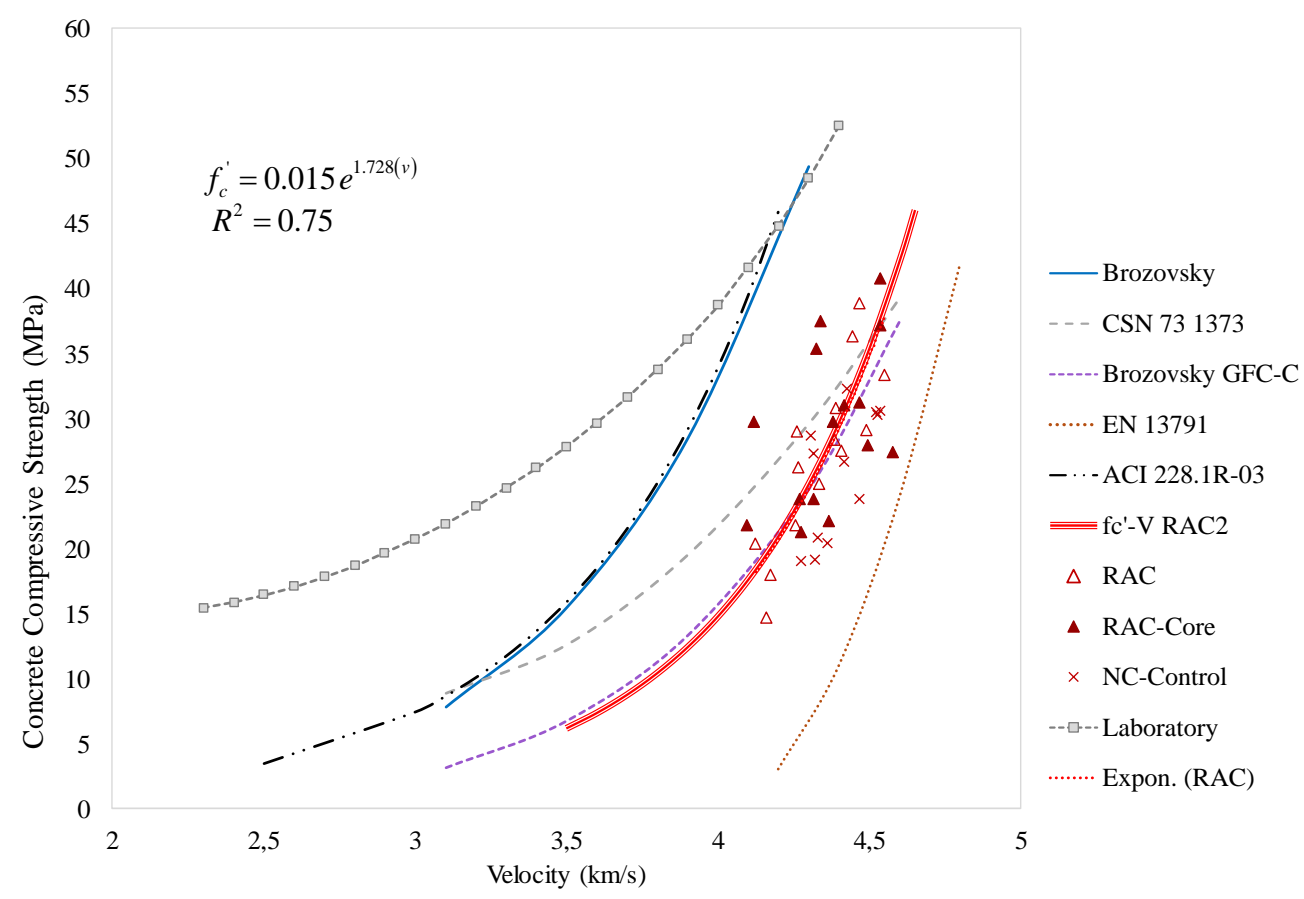

Figure 8 UPV and RAC compressive strength relationship 


\section{CONCLUSION}

In this research, the measurement of UPV equipment was carried out from the $4^{\text {th }}$ hour after casting. The wave propagation through RAC found to increase the age of the concrete (up to 28 days). The trend of the compressive strength decreases slightly beyond $28^{\text {th }}$ days. The UPV measurement of the four different levels of vertical beams was used to define the homogeneity of the RAC beam. The formulation of the homogeneity coefficient of Benaicha was originally intended for self-compacting concrete. There were no vertical beam samples that met the requirement of $\mathrm{HC} 2 \%$, homogeneity criterion with high stability. However, for the part of the analysis on the coefficient of variation, the measurements have coefficient of variation less than $10 \%$. The density variation of concrete in the upper part and the lower part is under $10 \%$. Moreover, differences greater than 5\% occurred only in the first 11 hours of the concrete age. Beyond age of 28 days, the difference is less than $4 \%$. Therefore, the variation of RAC is argued acceptable. This homogeneity condition can also be seen from the core-drilled sample.

The distribution of coarse aggregates in concrete that affect the concrete strength was shown by the UPV measurement and the compressive test. UPV measurements showed that the velocity in the lower part (the part with denser coarse aggregate) was higher than in the upper part (less dense coarse aggregate). The compressive test of core-drilled at the lower part samples had higher results than those of the upper part. Four of the 5 upper part samples had the lowest compressive stress compared to the middle and the lower part samples.

The model obtained from fc' - UPV has the same pattern as that of the Brozovsky GFC formulation with $16.34 \%$ of the coefficient of variation. Future studies can be carried out to see the impact of the different mixtures on the UPV measurements. In the case of larger beam construction, the prediction curve will help to predict the concrete strength for the demoulding and transportation processes without destroying the beam.

\section{REFERENCES}

Adnan, S. H., Loon, L. Y., Rahman, I. A., Saman, H. M., \& Soejoso, M. W. (2007). Compressive Strength of Recycled Aggregate Concrete With Various Percentage of Recycled Aggregate [Universiti Tun Hussein Onn Malaysia (UTHM)]. http://eprints.uthm.edu.my/id/eprint/2029/1/COMPRESSIVE_STRENGTH_OF_RECYCL ED_SURAYA_HANI_ADNAN.pdf

American Concrete Institite. (2001). ACI 555R-01: Removal and Reuse of Hardened Concrete. https://www.concrete.org/store/productdetail.aspx?ItemID=55501\&Format=DOWNLOA D\&Language $=$ English $\&$ Units $=$ US_AND_METRIC

American Concrete Institite. (2003). 228.1R-03: In-Place Methods to Estimate Concrete Strength.

https://www.concrete.org/store/productdetail.aspx?ItemID=228103\&Format=DOWNLOA D\&Language $=$ English \&Units=US_AND_METRIC

American Concrete Institite. (2010). 214.4R-10 Guide for Obtaining Cores and Interpreting Compressive Strength Results. https://www.concrete.org/portals/0/files/pdf/previews/214.4r-10web.pdf

American Concrete Institite. (2019). ACI 318-19: Building Code Requirements for Structural Concrete and Commentary. https://www.concrete.org/store/productdetail.aspx?ItemID=318U19\&Language=English

American Society for Testing and Materials. (2002). ASTM C597 - 02 Test Method for Pulse Velocity Through Concrete. https://doi.org/10.1520/C0597-02

American Society for Testing and Materials. (2018). ASTM C42 / C42M - 18a Standard Test Method for Obtaining and Testing Drilled Cores and Sawed Beams of Concrete. 
https://doi.org/10.1520/C0042_C0042M-18A

Arijoeni, E., \& Setiadi, S. (1998). Correlation Factor for Evaluating Concrete Compressive Strength Produced by Readymix at Job Site. $23^{\text {rd }}$ Conference on Our World in Concrete and Structures, Singapore 1998.

Badan Standarisasi Nasional. (2002). SNI 03-6898-2002 - Detail Tata cara pelaksanaan dan pengambilan dan pengujian kuat tekan beton inti. http://sni.litbang.pu.go.id/index.php?r=/sni/new/sni/detail/id/189

Badan Standarisasi Nasional. (2013). SNI 2847-2013 Persyaratan Beton Struktural Untuk Bangunan Gedung.

Benaicha, M., Jalbaud, O., Roguiez, X., Hafidi Alaoui, A., \& Burtschell, Y. (2015). Prediction of Self-Compacting Concrete homogeneity by ultrasonic velocity. In Alexandria Engineering Journal. https://doi.org/10.1016/j.aej.2015.08.002

British Standard Institute. (2009). Testing hardened concrete. Compressive strength of test specimens. https://shop.bsigroup.com/en/ProductDetail/?pid=000000000030253049

British Standards Institution. (2007). BS EN 13791:2007 - Assessment of in situ compressive strength in structures and precast concrete components. In Standard publication.

Brožovský, J. (2009). Evaluation of calculation correlation efficiency as mentioned in en 13791 in order to determination concrete compression strength by nondestructive testing. 10th International Conference of the Slovenian Society for Non-Destructive Testing: Application of Contemporary Non-Destructive Testing in Engineering.

Brožovský, J., Martinec, P., \& Matejka, O. (2005). Using of ultrasonic pulse method for prediction of strength of blended cements. 8th International Conference of the Slovenian Society for Non-Destructive Testing: Application of Contemporary Non-Destructive Testing in Engineering.

Brozovsky, J., Zach, J., \& Brozovsky Jr, J. (2007). Non-destructive testing of solid brick compression strength in structures. IV Conferencia Panamericana de END, Buenos Aires.

Dilger, W. H. (2000). Reinforced concrete: mechanics and design. In Canadian Journal of Civil Engineering (Vol. 27, Issue 6). https://doi.org/10.1139/100-087

Dini Sofyani, F., Handika, N., Tjahjono, E., \& Arijoeni, E. (2019). Flexural behaviour of reinforced lightweight concrete beam using hot water pre-treated oil palm shell coarse $\begin{array}{lllll}\text { aggregate. } \quad \text { MATEC } & \text { Web } & 01032 .\end{array}$ https://doi.org/10.1051/matecconf/201927601032

Duma, H. (2008). Studi Perilaku Kuat Lentur dan Susut pada Beton Agregat Daur Ulang. Universitas Indonesia.

Gehlot, T., Sankhla, D. S. S., Gehlot, D. S. S., \& Gupta, A. (2016). Study of Concrete Quality Assessment of Structural Elements Using Ultrasonic Pulse Velocity Test. IOSR Journal of Mechanical and Civil Engineering, 13(05), 15-22. https://doi.org/10.9790/16841305071522

Güneyli, H., Karahan, S., Güneyli, A., \& Yapıcı, N. (2017). Water content and temperature effect on ultrasonic pulse velocity of concrete. Russian Journal of Nondestructive Testing, 53(2), 159-166. https://doi.org/10.1134/S1061830917020024

Gupta, S. (2018). Comparison of Non-Destructive and Destructive Testing on Concrete: A Review. Trends in Civil Engineering and Its Architecture, 3(1). https://doi.org/10.32474/tceia.2018.03.000154

Handika, N., Sofyani, F. D., Tjahjono, E., \& Arijoeni, E. (2019). Cracking behavior of reinforced lightweight concrete beam using hot water pre-treated oil palm shell coarse aggregate. IOP Conference Series: Materials Science and Engineering, 473(1). https://doi.org/10.1088/1757-899X/473/1/012030

Karaiskos, G., Deraemaeker, A., Aggelis, D. G., \& Van Hemelrijck, D. (2015). Monitoring of concrete structures using the ultrasonic pulse velocity method. Smart Materials and 
Structures, 24(11). https://doi.org/10.1088/0964-1726/24/11/113001

Laboratory of Structural and Material Universitas Indonesia. (2009). Studies on The Relationship of Normal Concrete Laboratory of Structure and Material.

Lorenzi, A., Tisbierek, F. T., Carlos, L., \& Filho, S. (2007). Ultrasonic Pulse Velocity Analysis in Concrete Specimens 2 . Concrete Evaluation considering Nondestructive Testing. IV Conferencia Panamericana de END.

Majeed, F. H., \& Khalaf, M. A. (2018). Feasibility of using ultrasonic pulse velocity to measure the bond between new and old concrete. Journal of University of Babylon for Engineering Sciences, 26(1), $164-172$. https://www.journalofbabylon.com/index.php/JUBES/article/view/1188

Malešev, M., Radonjanin, V., \& Marinković, S. (2010). Recycled concrete as aggregate for structural concrete production. Sustainability, 2(5), 1204-1225. https://doi.org/10.3390/su2051204

Marastuti, P. (2014). Studi Penggunaan Agregat Kasar Daur Ulang dari Limbah Beton Padat dengan Mutu K350-K400 Terhadap Kuat Tekan, Kuat Lentur, dan Susut Pada Beton. Universitas Indonesia.

McCormac, J. C., \& Brown, R. H. (2015). Design of Reinforced Concrete, 10th Edition. Wiley. https://www.wiley.com/en-us/Design+of+Reinforced+Concrete,+10th+Edition-p9781118879108

Qasrawi, H., Marie, I., \& Tantawi, H. (2013). Use of recycled concrete rubbles as coarse aggregate in concrete.

Rao, S. K., Sravana, P., \& Rao, T. C. (2016). Experimental studies in Ultrasonic Pulse Velocity of roller compacted concrete pavement containing fly ash and M-sand Studies in Ultrasonic Pulse Velocity of Roller compacted concrete pavement. International Journal of Pavement Research and Technology, 9(4), 289-301. https://doi.org/10.1016/j.ijprt.2016.08.003

Saint-Pierre, F., Philibert, A., Giroux, B., \& Rivard, P. (2016). Concrete Quality Designation based on Ultrasonic Pulse Velocity. Construction and Building Materials, 125, 10221027. https://doi.org/10.1016/j.conbuildmat.2016.08.158

Vyas, C. M., \& Bhatt, D. R. (2013). Destructive Strength Properties of Recycled Coarse Aggregate. In International Journal of Innovative Technology and Exploring Engineering (IJITEE) (Issue 3).

Wulandari, A. (2008). Studi Perilaku Kuat Tekan dan Kuat Tarik Belah pada Beton dengan Menggunakan Agregat Daur Ulang. Universitas Indonesia.

Yap, S. P., Alengaram, U. J., \& Jumaat, M. Z. (2013). Enhancement of mechanical properties in polypropylene- and nylon-fibre reinforced oil palm shell concrete. Materials and Design, 49, 1034-1041. https://doi.org/10.1016/j.matdes.2013.02.070 